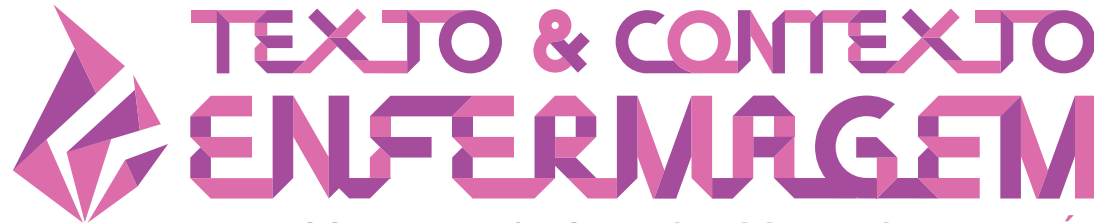

TEXT \& CONTEXT NURSING TEXTO \& CONTEXTO ENFERMERÍA

\section{PERCEPTION OF DIGNITY OF PATIENTS IN PALliATIVE CARE}

\author{
Marinete Esteves Franco ${ }^{1}$ \\ Marina de Góes Salvetti ${ }^{2}$ \\ Suzana Cristina Teixeira Donato ${ }^{2}$ \\ Ricardo Tavares de Carvalho' \\ Ednalda Maria Franck ${ }^{1}$
}

${ }^{1}$ Universidade de São Paulo, Hospital das Clínicas da Faculdade de Medicina. São Paulo, São Paulo, Brasil. ${ }^{2}$ Universidade de São Paulo, Departamento de Enfermagem Médico-Cirúrgica. São Paulo, São Paulo, Brasil.

\begin{abstract}
Objective: to understand the perception of dignity of patients in palliative care and to identify factors that may increase or decrease the sense of dignity.

Method: an exploratory study with a qualitative approach, carried in a Palliative Care Center in São Paulo (Brazil), with the Chochinov's Dignity Model as theoretical framework and content analysis as methodological framework. The participants of this study were 20 patients in palliative care, assessed through semi-structured interviews based on three questions: "What is dignity for you?", "What increases your dignity?", "What decreases your dignity?" The interviews were recorded with the patients' authorization, from September to November 2017, and transcribed for content analysis.

Results: the analysis of the perception of dignity allowed the identification of three categories: Correct person, Autonomy/independence and Socio-political factors. The factors that increased the sense of dignity were the following: Care, Independence/autonomy, Leisure/positive thinking/being with friends. And those that decreased it were the following: Behaviors/attitudes, Health status and Economic situation.

Conclusion: the perception of dignity of patients in palliative care was influenced by health professionals and caregivers. Being a "correct person", maintaining autonomy, being cared for and respected has increased the sense of dignity. Urban violence and the lack of compliance with accessibility policies have reduced the sense of dignity among palliative care patients.
\end{abstract}

DESCRIPTORS: Palliative care. Dignity. Perception. Terminality. Nursing. 


\section{PERCEPÇÃO DE DIGNIDADE DE PACIENTES EM CUIDADOS PALIATIVOS}

\section{RESUMO}

Objetivo: compreender a percepção de dignidade de pacientes em cuidados paliativos e identificar os fatores que podem aumentar ou diminuir o senso de dignidade.

Método: estudo exploratório com abordagem qualitativa, realizado em um Núcleo de Cuidados Paliativos de São Paulo (Brasil), cujo referencial teórico foi o Modelo de Dignidade de Chochinov e o referencial metodológico, a análise de conteúdo. Os participantes deste estudo foram 20 pacientes em cuidados paliativos, avaliados por meio de entrevista semiestruturada baseada em três questões: "O que é dignidade para você?", "O que aumenta sua dignidade?", "O que diminui sua dignidade?". As entrevistas foram gravadas com autorização dos pacientes, no período de setembro a novembro de 2017, e transcritas para análise de conteúdo.

Resultados: a análise da percepção de dignidade permitiu a identificação de três categorias: Pessoa correta, Autonomia/independência e Fatores sociopolíticos. Os fatores que aumentaram o senso de dignidade foram: Cuidado, Independência/autonomia, Lazer/pensar positivo/estar com os amigos e os que diminuíram foram: Comportamentos/atitudes, Estado de saúde e Situação econômica.

Conclusão: a percepção de dignidade de pacientes em cuidados paliativos foi influenciada por profissionais de saúde e cuidadores. Ser uma pessoa correta, manter a autonomia, ser cuidado e ter respeito aumentaram o senso de dignidade. A violência urbana e a ausência do cumprimento de políticas de acessibilidade reduziram o senso de dignidade entre os pacientes em cuidados paliativos.

DESCRITORES: Cuidados Paliativos. Dignidade. Percepção. Terminalidade. Enfermagem.

\section{PERCEPCIÓN DE LOS PACIENTES EN CUIDADOS PALIATIVOS CON RESPECTO A LA DIGNIDAD}

\section{RESUMEN}

Objetivo: comprender la percepción de los pacientes en cuidados paliativos con respecto a la dignidad e identificar los factores que pueden aumentar o disminuir la sensación de dignidad.

Método: estudio exploratorio con abordaje cualitativo, realizado en un Centro de Cuidados Paliativos en São Paulo (Brasil) cuyo referencial teórico fue el Modelo de Dignidad de Chochinov y en el que se utilizó el análisis de contenido como referencial metodológico. Los participantes de este estudio fueron 20 pacientes en cuidados paliativos, evaluados por medio de una entrevista semiestructurada basada en tres preguntas: "¿Qué significa la dignidad para usted?”, “¿Qué aumenta su nivel de dignidad?" y “¿Qué disminuye su nivel de dignidad?". Las entrevistas se grabaron con la autorización de los pacientes, durante el período de septiembre a noviembre de 2017, y se las transcribió para realizar el análisis de contenido.

Resultados: el análisis de la percepción de la dignidad permitió identificar tres categorías: Persona correcta, Autonomía/independencia y Factores sociopolíticos. Los factores que aumentaron la sensación de dignidad fueron los siguientes: Cuidado, Independencia/autonomía, Tiempo libre/pensamiento positivo/estar con amigos. Y los que la disminuyeron fueron los siguientes: Comportamientos/actitudes, Estado de salud y Situación económica.

Conclusión: la percepción de los pacientes en cuidados paliativos con respecto a la dignidad se vio influenciada por los profesionales de la salud y por los cuidadores. Ser una "persona correcta", mantener la autonomía, ser cuidado e tener respeto aumentaron la sensación de dignidad. La violencia urbana y la ausencia del cumplimiento de políticas de accesibilidad disminuyeron la sensación de dignidad entre los pacientes en cuidados paliativos.

DESCRIPTORES: Cuidados Paliativos. Dignidad. Percepción. Terminalidad. Enfermería. 


\section{INTRODUCTION}

Human dignity has many meanings and varies according to context and sociocultural structure. Such a word derives from the Latin dignitas, which means "merit," and dignus, "value".

Throughout history, dignity has been linked to religion and merit; with the Enlightenment, this concept migrated to Philosophy, whose foundation is reason, and came to have moral value. ${ }^{2}$ From the work of philosopher Emmanuel Kant, ${ }^{3}$ it was dissociated from the philosophical and religious fields and came to be considered as a social and political concept, inherent to human beings, and based on autonomy. ${ }^{2-4}$

Over the course of the $20^{\text {th }}$ century, especially in the postwar period, it became a State and society political objective, registered through the United Nations Charter and through the Universal Declaration of Human Rights, first published in 1948, where human dignity is taken as essence. ${ }^{4}$ It was later incorporated into the legal field through its configuration in Federal Constitutions, such as the Mexican, German, French, and Spanish ones, among others. ${ }^{2}$

The term dignity is widely used by health care professionals. It is present in codes of professional ethics but, as in the humanities and legal sciences, its concept is still poorly defined. Thus, studies have been conducted in order to clarify this concept. ${ }^{1-2}$

A study conducted with professionals and socially marginalized people has shown that there are two forms of dignity: Human Dignity, abstract and universal, which cannot be created or destroyed; and Social Dignity, which includes the Dignity of the Self (self-respect and self-esteem) and the Dignity of Relationship (respect and value conveyed through individual and collective behavior). This work also identified that dignity is influenced by customs and traditions, and that individuals tend to act to create, maintain, defend, and claim their own dignity and that of others, even in difficult situations. ${ }^{5}$

Chochinov analyzed patients in palliative care diagnosed with advanced cancer and proposed a conceptual model of dignity, which constitutes the theoretical framework of this study. ${ }^{6}$ In this model, the perception of dignity is composed of three elements: concerns related to the disease (physical and psychological factors); personal resources of dignity (spiritual or psychological factors that interfere with the sense of dignity); and social resources (factors such as social context, challenges, positive aspects and suffering). ${ }^{6}$

The systematic review that analyzed the concept of dying with dignity concluded that its main attributes are absence of pain, respect for body and beliefs, financial and emotional support, and protection of privacy. ${ }^{7}$ Maintaining human dignity, for some patients, is more important than their own health. Thus, it is essential that health professionals understand the meaning of dignity from the patient's point of view. ${ }^{6-7}$

Dignity is present in human life and culture, and integrates the experiences of victories and sufferings. ${ }^{8}$ Despite advances in studies on the concept of dignity, there is still little national research on the topic, and little is known about the perception of dignity of patients in the context of palliative care. ${ }^{9-10}$

Thereby, the purpose of this article is to understand the perception of dignity of patients in palliative care and to identify factors that may increase or decrease their sense of dignity.

\section{METHOD}

An exploratory study with a qualitative approach, focused on individuals' life experience, allows to unveil still little explored processes, singularities and meanings from the point of view of the social actors. ${ }^{11-12}$ This research perspective was chosen because the object of study in this research corresponds to an action that materializes in a social context, marked by intersubjectivity. 
This study was carried out in the city of São Paulo, in a Palliative Care Center (PCN) of a large public hospital. The PCN includes Nursing, Interconsultation, Outpatient, Hospice and Interdisciplinary Home Care Center (IHCC) services. All services have an interdisciplinary team specialized in palliative care.

This study included adult patients with preserved communication skills and excluded patients with decreased level of consciousness, delirium, diagnosed with advanced dementia or with uncontrolled symptoms. For data collection in the outpatient clinic, patients participated from the second consultation onwards, due to the possibility of uncontrolled symptoms in patients from the first consultation.

Twenty individuals were interviewed, 11 from the outpatient clinic, eight from the ward and one from the IHCC. The survey of eligible patients was based on data from medical records and performed according to the evaluation and indication of the referred units' nurses, who evaluated the patients according to the inclusion and exclusion criteria of the study. After this initial selection, patients were invited to participate in the research and, for those who accepted, an individual meeting was scheduled for the interviews.

The project was submitted and approved by the Research Ethics Committee (REC) of the Institution where the study was conducted. The interviews took place upon acceptance and signature of the Informed Consent Form by the patient or legal representative, as provided for in Resolution 466/12 of the National Health Council, which permeated the entire course of this research. Thus, the collected data was treated confidentially and used only for the purposes of this study.

Whereas the notion of human dignity depends on the socio-cultural context and varies with time and space,,$^{2-6}$ some instruments were used to perform the socio-demographic and clinical characterization of the study participants: a form with socio-demographic and clinical data, the Edmonton Symptom Scale (ESAS) and the Functional Assessment Scale (Palliative Performance Scale - PPS).

The Edmonton Symptom Scale (ESAS) was used to measure patients' symptoms in order to verify the presence of discomfort at the time of the interview. ESAS is an easy tool for health professionals to apply, as well as being of clinical utility. It was validated for Portuguese in 2015 and assesses nine symptoms such as pain, fatigue, nausea, depression, anxiety, somnolence, appetite, well-being and dyspnea, with room for "other symptoms". Symptom intensity is graded from 0 to 10 points, and higher scores represent worse symptom intensity. ${ }^{13}$

The PPS scale aims to assess patient functionality in relation to ambulation, disease activity and evidence, self-care, food intake and level of consciousness. It has 11 "performance" levels, from 0 to 100 , divided into intervals of 10, i.e., there are no intermediate values. This scale should be used daily for inpatients, in all outpatient appointments and home visits. ${ }^{14}$

After applying the socio-demographic form and the scales described above, semi-structured interviews were conducted, in private and uninterrupted environments, through the following guiding questions: "What is dignity for you?, What increases your dignity?, and What decreases your dignity?".

The interviews were recorded on a digital audio device in order to promote greater fidelity to the process of capturing ideas. After the interviews, the audios were transcribed, respecting the sequence, language, repetitions and pauses performed..$^{15}$

For the content analysis of the interview transcripts, the content analysis framework was used,$^{16}$ developed according to the following stages: fluctuating and comprehensive reading of the material, in order to be impregnated with the content of the interviews; transformation of content into units, where a re-reading of the material was performed in order to define the units of analysis; categorization, where the units of analysis were grouped considering common parts, according to the meaning given by the patients - the goal was to conform with the characteristics of completeness, 
representativeness, homogeneity and relevance -; inference and interpretation, where a synthesis was performed of the interpretation of speech descriptions, their representations and meanings. ${ }^{17}$

\section{RESULTS}

During the data collection period, 100 individuals were treated at the Outpatient Clinic, in which 11 of them were eligible for the study. In the same period, 30 patients were admitted to the ward, and eight met the inclusion criteria. The IHCC patient was referred to the study after evaluation by the nurse responsible for the service, according to the inclusion and exclusion criteria. The analysis of the participants' characteristics showed a predominance of males $(60 \%)$, individuals living without a partner $(60 \%)$, Catholics (55\%), with seven years mean schooling and mean age of 60 years old (Table 1).

Table 1 - Socio-demographic characteristics of the study participants. São Paulo, SP, Brazil, 2017. $(n=20)$

\begin{tabular}{lcc}
\hline Variable & $\mathbf{n}(\%)$ & Mean (SD*) \\
\hline Gender & & \\
Female & $8(40)$ & \\
Male & $12(60)$ & $60.7(18.3)$ \\
Age (years) & & $6.9(6.5)$ \\
Schooling (years) & & \\
Marital status & $6(40)$ & \\
Has a partner & $12(60)$ \\
No partner & \\
Religion & $11(55)$ & \\
Catholic & $6(30)$ & \\
Evangelical & $3(15)$ \\
Others & & \\
Diagnoses & $6(30)$ \\
Cardiovascular & $4(20)$ \\
Malignant neoplasm & $3(15)$ \\
Pulmonary & $3(15)$ \\
Gastrointestinal & $4(20)$ \\
Others & \\
Palliative Performance Scale & \\
Advanced Directives & $17(85)$ \\
Yes & $3(15)$ \\
No & $5(25)$ \\
Outcome & $15(75)$ & \\
Death & \\
Ambulatory Care &
\end{tabular}

The mean follow-up time with the palliative care team was ten months, and participants had, on average, two hospitalizations in the year. The main medical diagnosis was cardiovascular disease and the median of functionality in the PPS was 60 . Among the participants, $85 \%$ had defined Advanced Directives and $25 \%$ passed away before the end of this research, with a mean time of 
30 days after the interview. The most prevalent symptoms were appetite changes, anxiety, fatigue and sadness.

The mean recorded interview time was 8 minutes, the shortest being 1 minute and 16 seconds and the longest being 23 minutes. The total mean interaction time was 27 minutes; the shortest lasted 5 minutes and the longest, 90 minutes. This variation of time occurred based on the objective of the interview to be achieved, both with the shortest and the longest, being the researcher and patient free from external interference, such as activities related to personal hygiene, medication administration, family reunion, and visits, among others.

Some symbols were used to help in understanding the transcriptions, since they are a clipping of the reality that was experienced during the interview. ${ }^{15}$ These symbols are the following:

() - Words added with the intention of the phrase/excerpt to make sense;

$/ / . . / /$ - Used to represent that there was a deleted section;

[] - Used to designate emotions, pause, silence.

The patients' speeches were numbered according to the order in which the interviews took place, with the letter $P$ followed by an Arabic number.

\section{What is dignity to you?}

For this question, three categories emerged: Correct person, Autonomy/independence and Socio-political factors. Some patients have failed to answer on what dignity is, and these reports are also set forth below.

\section{Correct person}

Many participants have related dignity to being a "correct person", and this category can still be subdivided into two parts: one related to the way one relates to oneself and the other to the way one relates to other people. The association of dignity with the presence of rigor and honor to commitments is evidenced, as well as elements such as honesty, respect and character.

Dignity is the person, ahm... In short, that's correct. In all senses. Almost equal to character. $/ / . . / /$ It is the righteous person, the person who honors their commitments, who obeys norms and rules (P6).

Ah, a person who is straight, rolls along with life properly, to be a good person. Whatever they achieve is theirs, on their own merit, isn't it?, not on anyone else. I think that's it (P9).

\section{Autonomy/Independence}

It is noted that this category was very significant in the patients' view, as it refers to the ability to make decisions about the direction of life, self-care and dependence on other people.

Dignity for me is living up to my values, living up to the principles that I believe in and govern my life. And having freedom and autonomy to choose this path. It is being treated in a non-violent, non-humiliating and respectful manner (P13).

Autonomy. Total autonomy, physical and mental. For me I think it summarizes well what I think of dignity... //...// Dignity is to respect the rights of others, right? Also. //...// For you to be the master of your life (P18).

\section{Socio-political factors}

In this category we find some answers that refer to the economic, social and political characteristics experienced by the patients. 
And also being able to live a quiet life without mistakes and to go out of the house without been mugged, these things. I think that would also be more worthy for all of us (P20).

//...// These people (politicians) should think very seriously in their bed time all day, or in the morning when they shave, wake up and look in the mirror and say, "Wow, I'm dealing with my population who voted for me with respect. What am I going to do for them today? //...// Not only the ones who voted for me, even those who went against, I have to show them why I am here (P11).

Some patients expressed doubt and could not answer what the word dignity meant, answered all the questions in their own words:

How do you explain it? (laughs) How am I going to explain it to you? Dignity... (silence). Do you know that I don't know how to explain it?! (laughs) //...// Oh, after a certain age, you know, I don't think about these things anymore... (P16).

\section{What increases your dignity?}

For this question, three categories was defined: Care, Autonomy/Independence, Leisure/ Positive thinking/Being with friends. It is noteworthy that the sense of respect and autonomy reported below differs from what the patients answered in the first question.

\section{Care}

In this category, it is noted that the answers refer to both self-care and the care they receive from both family members and the health team. The fact of being remembered is also a form of care, as it brings comfort to the patient.

Respect. Conversation. //...// I have, I've had some clashes with doctors in consultations because the consultation is, five to ten minutes, most of the time they don't even look at the patient in the eyes. And... In half an hour of conversation, I feel much better... I think they are not yet prepared to hear the patient's outbursts. Mostly from a patient who has some serious illness. This is what I perceive (P18).

//...// It's like that, as you nurses, right? You provide care, you bathe, you change clothes, you... //...//, do everything a sick person needs as help from others. This is love, this is being faithful, this is being obedient to the things of God. //..// (P2).

//...// I have relatives. I have already received many, many visits! //...// [patient cries] I feel thrilled about certain hours, depending on the fact it moves me deep inside. Because I think, "Gosh, they remembered me! That's cool!". I/...// I'm sitting reading, my grandson goes by, he moves my head on the couch. Goes by and says "Hi, Grandpa!", I feel good, I feel very good, although I'm in this condition here, disrupting their lives. //...// That's what moves, that's what gives me dignity. I think that gives us dignity; when others care about us (P11).

\section{Autonomy/independence}

In this category, the issue of work, health and independence is noted as a factor for the acquisition of autonomy.

It's you having a job to make a living. //...// because you don't have to depend on anyone. If you want, you go and buy. You travel, buy your medications. If you get sick and are broke, you're useless, right? It depends on you, you depends on the other, not everyone helps you... //...// When you are healthy, you do everything, right? This is the most important thing, when you are healthy, you pull it off, right? With no health, it's hard... (P10). 


\section{Leisure/positive thinking/being with friends}

better.

In this category, responses emerged regarding the daily activities that the patients do to feel

//...// Then I talk to someone, when I come back, I'm feeling good already. //...// I go to my friend's house, I talk to her. Then I go to my neighbor's house that lives in my backyard, I go and talk to her a little bit and so on. //...// When I get back (home), I'm cool. (P3)

Whenever I come for appointments, tiring and all, but I always look for a ride, some leisure, something. I think if you look for, let's say, a relief valve, it helps a lot to increase your dignity. (P20)

\section{What diminishes your dignity?}

For this question, three categories was defined: Behaviors/Attitudes, Health status and Economic situation.

\section{Behavior/Attitudes}

In this category, it is observed that attitudes such as omission, lying, lack of respect and nonempathic attitudes favor the reduction of the sense of dignity.

You are sloppy, right, you are careless about yourself, you do not face things as they are. (P4)

It's the person... it's the other individual not considering you as you are. Not paying attention to you, not respecting your qualities. //...// For whatever reason, whatever. If I were a Corinthian, if I were a Lulist or not, whatever I were, I want you to respect me as I am, as I respect you. //...//(P11).

\section{Health status}

In this category, it is noted that multiple comorbidities, the understanding of family members about the patient's condition, the way they deal with the disease and the education of the general population also interfere with the patient's recovery process and the patient's sense of dignity.

You do nothing, you depend on others. //...// Not everyone is available for you, right? He has good will, but is not available, right? //...// It is horrible to depend on others. //...// (P10).

I spent four, seven years treating, no doctor found out what disease it was. //...// I worked seven years on this scenery, like this. //...// I spent so much time with this disease and now... It's bad, right? (P10).

//...// But I don't go out where there is a lot of people. Shopping Mall... Restaurant... Where there is a lot of movement I don't go out, because people really do not respect. Starting in the parking lot, right? //...// I came to perceive this after I had to start using a wheelchair, sometimes, sometimes people don't do it out of meanness. Because they can't imagine, they see us in the chair, and think that everything is cool, it's okay, right? They don't know the troubles that we have with the intestine, with the bladder... Don't know about the needs. So, at times, I miss this lack of respect for... For anyone, right? //...// (P18).

\section{Economic/political situation}

In this category, social and political vulnerability is also reported as a factor responsible for reducing the dignity of patients.

That my salary is a pittance. This month now, I was mugged and l've got a lot of bills to pay: credit card, phone bill to pay, everything, everything. //...// But if I had reacted, I would have gone too, right? //...// I was going to take a very big risk. Me, with a cane, unable to walk straight, and they took me somewhere. And I like a duck, I fell like a silly duck... But I'm alive here, thank God (P3). 
It is, for example, that we see all these, these frauds from government people, from families, right? When you see those people putting money in their pockets, they drop it there, so I stay home thinking: this guy is, look, I, I, has no character, no dignity, how does he live with his family, right? Is it making these frauds? //...// Unfortunately, the people, Brazil lives, lives with a lot of politicians who have no dignity to be up there, and it wqs us who put them up there, right? (P12).

\section{DISCUSSION}

In this study, it is observed that the profile of patients differs from the profile of those who participated in a study conducted in Canada ${ }^{6}$ with 50 participants ( $46 \%$ male and $54 \%$ female). This study had 20 participants ( $60 \%$ male and $40 \%$ female). The average age in this study was 60 years old; in the Canadian study, 69. The main diagnosis in the Canadian study was neoplastic disease; in this one, cardiovascular disease followed by neoplastic and pulmonary diseases (Table 1). The mean functionality (PPS) of this study was $60 \%$ and the follow-up time in PC was 10 months, both data were not reported in the canadian study.

Both surveys were conducted in places where palliative care services were provided by specialized staff. In the canadian study only individuals who could read and write participated, and in the present study schooling ranged from 0 to 20 years. It is noteworthy that in the canadian study, patients in ambulatory and ward care were included; in this study, in addition to the ambulatory and nursing ward, a patient from the home care service was included.

In this study, the average time between interview and death was approximately 30 days and in the canadian study, 82 days. This suggests that the participants in this research had the disease in a "more advanced" phase than the patients in the canadian study.

In this paper, it is evident that the term dignity is full of meanings, and that they may vary over time according to people's economic, social and health conditions. On the other hand, some patients found it difficult to define the term. Although the concept of dignity has been dissociated from the religious field, ${ }^{2-3}$ in this study it was associated with religious issues.

Both in this paper and in the canadian one, ${ }^{6}$ items such as self-esteem, interpersonal relationships - whether with friends, family and health care - positive thinking, independence and autonomy were described as factors that increase the sense of dignity. In this sense, the perception of dignity can be related to the concept of a dignified death, since dying with dignity is also important for family members and health professionals. ${ }^{7,18-19}$

Responses regarding the increase of dignity consider autonomy as a concept related to decision-making capacity, which in PC is usually shared with the family and even with the patient, when the patient has a preserved level of consciousness and reports the desire to participate in the decisions about their own treatment. ${ }^{20}$ With the advancement of the media and social networks, more and more patients and family members have access to information on diagnoses, signs and symptoms, treatments, interpretation of exams; ${ }^{21}$ it is then up to the health team to manage the proper interpretation of this information. The role of the health care team in assisting the patient in decisionmaking is challenging, as well as providing them with information to express their preferences, thus ensuring that autonomy is preserved and, hence, dignity too. ${ }^{20,22-23}$

When autonomy was related to a decreased sense of dignity, it was associated with independence to perform daily basic activities and with the ability to self-care. This concept was also observed in the canadian study ${ }^{6}$ and in a systematic review work in which the author analyzed the publications on dignity at the end of life. ${ }^{24}$

To cover biological, psychological, social and spiritual aspects, PC care is necessarily provided by a multidisciplinary team so that all dimensions of care are involved. ${ }^{25-27}$ Factors such as communication 
and interaction with the health team also emerged as relevant, which may influence the increase or decrease of patients' perception of dignity. ${ }^{23,28}$

Team attitudes contribute to the varying sense of dignity of these patients, and teams with greater knowledge of the later stages of life are able to provide greater comfort to these individuals. ${ }^{7.23}$ Behaviors such as eye contact, smiling, empathy and sensitivity to patient values, as well as maintaining privacy, are actions that contribute to patient satisfaction, as well as to greater bonding and trust, 7,19,29 fundamental characteristics for patient care, with a positive impact on their sense of dignity. The absence of these factors contributes to a decreased sense of dignity.

Public policies for accessibility and insertion of patients in society - whether physically handicapped or dependent on oxygen therapy - also interfere with the perception of dignity and autonomy, since they may compromise the individual desire to occupy spaces other than their own residence, factors evidenced on this paper. Specific facts like these can be defined as "Social Dignity", since it is considered part of human dignity and is acquired through social interactions. ${ }^{9}$

Working conditions, as well as communication and interaction among the multidisciplinary team, also interfere with the involvement of professionals with patients. ${ }^{30}$ Communication is a fundamental aspect that has a direct effect on patient care and may affect end-of-life care. ${ }^{24,31}$ In addition, facts such as the workload of the nursing staff, gaps in difficult news reporting, as well as lack of material resources and inadequate physical structure also impact negatively on patient assistance in palliative care. $^{23}$

Lack of continuing education in communication strategies for patients in palliative care ${ }^{30}$ and non-professional involvement with death-related issues interfere with the patients' sense of dignity, as dignity "can come and go" according to the actions of other subjects. ${ }^{31-32}$ Therefore, it is necessary to insert a discussion on the process of death and dying in the training courses of the health team. ${ }^{23,31,33-36}$

Violence is also present in this portion of the population, whether related to family members or to people outside the scope of the elderly. It can be in the way of theft, neglect and financial abuse. It is estimated that of the 901 million people over 60 years old, $15 \%$ were victims of some form of abuse; and it is suggested that this number may be higher since such crimes are underreported. ${ }^{37-38}$ Situations of social vulnerability cause dignity to be violated and it is important to create mechanisms to guarantee what the Universal Declaration of Human Rights stipulates, ensuring that dignity is "protected". 39

The relationship between social vulnerability, violence and dignity observed in the present study did not occur in the canadian study, and this difference can be explained by the brazilian political and social situation, which appears in the speech of many participants of this study associated with the perception of dignity.

Given the current scenario of population aging, ${ }^{40}$ the increase in non-transmittable as well as in oncological chronic diseases, and the importance of palliative care, this research contributes to the understanding of the perception of dignity of patients in PC, providing elements for future intervention studies in this area, aiming to improve the dignity of these patients.

One of the limitations of this study was the exclusive inclusion of patients with preserved verbal communication. In addition, issues related to spirituality and to the process of dying may also interfere with the sense of dignity, and this paper has not explored such relationships. 


\section{CONCLUSION}

The analysis of the perception of dignity of patients in palliative care brought about reflections related to self-esteem, to coping with the limitations imposed by the disease, to autonomy and care, as well as to social and political issues. Factors associated with the political moment in Brazil and with urban violence also emerged, influencing the perception of dignity of these patients.

The health team was signaled as an important factor for the sense of dignity, either by direct or indirect care. Being a "correct person", maintaining autonomy, being cared for and being respected has increased the sense of dignity. Urban violence and the lack of compliance with accessibility policies have reduced the sense of dignity among patients in palliative care.

Considering that the perception of dignity is a dynamic process and that it can be modified throughout life, depending on the context and the situations experienced, it is suggested that other studies seek to explore this issue from other perspectives, such as health professionals and relatives. Health care planning should consider factors that can enhance the dignity of patients in palliative care, as well as direct the creation of policies and routines that value what is important to these patients.

\section{REFERENCES}

1. Julião M. Eficácia da Terapia da Dignidade no Sofrimento Psicossocial de Doentes em Fim de Vida Seguidos em Cuidados Paliativos: Ensaio Clínico Aleatorizado e Controlado [thesis]. Lisboa (PT): Universidade de Lisboa, Faculdade de Medicina; 2014 [cited 2018 Apr 18]. Available from: http://repositorio.ul.pt/handle/10451/11700

2. Barroso LR. A Dignidade da Pessoa Humana no Direito Constitucional Contemporâneo: Natureza Jurídica, Conteúdos Mínimos e Critérios de Aplicação. Versão provisória para debate público; 2010 Dec. [cited 2018 Apr 18]. Available from: http://luisrobertobarroso.com.br/wp-content/ uploads/2016/06/Dignidade_texto-base_11dez2010.pdf

3. Kant I. Fundamentação da Metafísica dos Costumes. Lisboa (PT): Edições 70; 2011.

4. Hernandez MC. A Conferência de Viena e a Internacionalização dos Direitos Humanos. Curitiba (BR): Juruá; 2014.

5. Jacobson N. A taxonomy of dignity: a grounded theory study. BMC International Health and Human Rights [Internet]. 2009 [cited 2018 Apr 17]; 9:3. Available from: https://dx.doi.org/10.1186/1472698X-9-3

6. Chochinov HM, Hack T, McClement S, Kristjanson L, Harlos M. Dignity in the terminally ill: a developing empirical model. Social Scie Med [Internet]. 2002 [cited 2018 Apr 18]; 54(3):433-43. Available from: https://dx.doi.org/10.1016/S0277-9536(01)00084-3

7. Hemati Z, Ashouri E, AllahBakhshian M, Pourfarzad Z, Shirani F, Safazadeh S, et al. Dying with dignity: a concept analysis. J Clinical Nurs [Internet]. 2016 [cited 2018 Apr 19]; 25(9-10):121828. Available from: https://dx.doi.org/10.1111/jocn.13143

8. Julião M, Oliveira F, Nunes B, Carneiro AV, Barbosa A. Effect of dignity therapy on end-of-life psychological distress in terminally ill Portuguese patients: A randomized controlled trial. Palliat Support Care [Internet]. 2017 [cited 2018 Apr 17];15(6):1-10. Available from: https://dx.doi. org/10.1017/S1478951516001140

9. Juliao M, Barbosa A, Oliveira F, Nunes B, Carneiro AV. Efficacy of dignity therapy for depression and anxiety in terminally ill patients: Early results of a randomized controlled trial. Palliat Support Care [Internet]. 2013 [cited 2018 Apr 19];11(6):481-9. Available from: https://dx.doi.org/10.1017/ S1478951512000892 
10. Chochinov HM, Hack T, Hassard T, Kristjanson LJ, McClement S, Harlos M. Dignity therapy: A novel psychotherapeutic intervention for patients near the end of life. Jf Clinical Oncol [Internet]. 2005 [cited 2018 Apr 19]; 23(24):5520-5. Available from: https://dx.doi.org/10.1200/JCO.2005.08.391

11. Minayo MCS. O desafio do conhecimento: pesquisa qualitativa em saúde. 14th ed. São Paulo (BR): Hucitec; 2014.

12. Taquete SR. Analise de Dados de Pequisa Qualitativa em Saúde. Atas - Investigação Qualitativa em Saúde [Internet]. 2016; [cited 2018 Oct 17]. Available from: https://proceedings.ciaiq.org/ index.php/ciaiq2016/article/view/790

13. Paiva CE, Manfredini LL, Paiva BSR, Hui D, Bruera E. The Brazilian Version of the Edmonton Symptom Assessment System (ESAS) Is a Feasible, Valid and Reliable Instrument for the Measurement of Symptoms in Advanced Cancer Patients. Plos One [Internet]. 2015 [cited 2018 Apr 19];10(7):13. Available from: https://doi.org/10.1371/journal.pone.0132073

14. Maciel MGS, Carvalho RT. Palliative Performance Scale PPS Versão 2 [Internet]. 2009; [cited 2018 Apr 19]. Available from: http://www.victoriahospice.org/sites/default/files/pps_portugese_0.pdf

15. Manzini EJ. Considerações Sobre a Transcrição de Entrevistas. Marília(BR): UNESP [Internet]; [date unknown] [cited 2018 Apr 19] Available from: http://www.oneesp.ufscar.br/texto_orientacao_ transcricao_entrevista

16. Bardin L. Análise de Conteúdo. 5th ed. Lisboa (PT): Edições 70; 2009.

17. Caregnato RCA, Mutti R. Pesquisa qualitativa: análise de discurso versus análise de conteúdo. Texto Contexto Enferm [Internet]. 2006 [cited 2018 Apr 19]; 15(4):679-84. Available from: https:// dx.doi.org/10.1590/S0104-07072006000400017

18. Meier EA, Gallegos JV, Montross-Thomas LP, Depp CA, Irwin SA, Jeste DV. Defining a Good Death (Successful Dying): Literature Review and a Call for Research and Public Dialogue. Am J Geriatric Psyc [Internet]. 2016 [cited 2018 Apr 18]; 24(4):261-71. Available from: https://dx.doi. org/10.1016/j.jagp.2016.01.135

19. Guo Q, Jacelon CS. An integrative review of dignity in end-of-life care. Palliative Medicine. [Internet]. 2014 [cited 2018 Oct 17]; 28(7):931-40. Available from: https://dx.doi.org/10.1177/0269216314528399

20. Crispim DH, Bernardes DCR. Comunicação em Cuidados Paliativos. In: Carvalho RT, Souza MRB, Franck EM, Polastrini RTV, Crispim D, Jales SMCP, et al. Manual da Residência de Cuidados Paliativos. Barueri(BR): Manole; 2018.

21. Kilbride MK, Joffe S. The New Age of Patient Autonomy Implications for the Patient-Physician Relationship. JAMA. 2018, [cited 2018 Oct 17]; 320 (19): 1973-74. Available from: https://dx.doi. org/10.1001/jama.2018.14382

22. Peruzzo-Júnior L. Autonomy, care and respect: the debate on assisted extension of life. Rev. Bioética y Derecho [Internet]. 2017 [cited 2018 Oct 17]; (39):121-34. Available from: http://scielo. isciii.es/scielo.php?script=sci_arttext\&pid=S1886-58872017000100008\&lng=es

23. Prado RT, Leite JL, Silva IR, Silva LJ, Castro EAB. The process of dying/death: intervening conditions to the nursing care management. Rev Bras Enferm [Internet]. 2018 [cited 2018 Oct 29]; 71(4):2005-13. Available from: https://dx.doi.org/10.1590/0034-7167-2017-0173

24. Rodríguez-Prat A, Monforte-Royo C, Porta-Sales J, Escribano X, Balaguer A. Patient perspectives of dignity, autonomy and control at the end of life: systematic review and meta-ethnography. Plos One [Internet]. 2016 [cited 2018 Oct 17]. Available from: https://doi.org/10.1371/journal. pone.0151435 
25. World Health Organization [Página na Internet]. WHO definition of Palliative Care. Geneva: WHO; 2017 [cited 2017 May 03]. Available from: http://www.who.int/cancer/palliative/definition/en/

26. Kelley AS, Morrison RS. Palliative Care for the Seriously III. N Engl J Med [Internet]. 2015 [cited 2018 Oct 29]; 373(8):747-55. Available from: Available from: https://dx.doi.org/10.1056/ NEJMra1404684

27. Carvalho RT. Cuidados Paliativos - Conceitos e Princípios. In: Carvalho RT, Souza MRB, Franck EM, Polastrini RTV, Crispim D, Jales SMCP, et al. Manual da Residência de Cuidados Paliativos. Barueri [BR] Manole; 2018.

28. Chochinov HM, Hack T, Hassard T, Kristjanson LJ, McClement S, Harlos M. Dignity and psychotherapeutic considerations in end-of-life care. J Palliative Care [Internet]. 2004 [cited 2018 Oct 29]; 20(3):134-42. Available from: https://search.proquest.com/openview/1a1a6aee2 07f4624aaef420b464969de/1?pq-origsite=gscholar\&cbl=31334

29. Lagos Sánchez ZE, Matos-Pimenta CA, Urrutia MT. La calidez en enfermería: formulación de constructo y variables relacionadas. Investig Enferm Imagen Desarr. [Internet]. 2016 [cited 2018 Oct 29]; 18(1):95-113. Available from: https://doi.org/10.11144/Javeriana.ie18-1.cefc

30. Gail G, B Emily, F Lindsay, Rushton C, Beach MC, Carrese J, et al. Health Care Professionals' Perceptions and Experiences of Respect and Dignity in the Intensive Care Unit. Narrative Inquiry in Bioethics [Internet]. 2015 [cited 2018 Oct 29]; 5 (1):27-42. Available from: https://dx.doi. org/10.1353/nib.2015.0001

31. Farrel C, Heaven C. Understanding the impact of chemotherapy on dignity for older people and their partners. Eur J Oncol Nurs. 2018 [cited 2018 Oct 29];36: 82-8. [Internet]. Available from: https://dx.doi.org/doi.org/10.1016/j.ejon.2018.05.008

32. Nordenfelt L. The varieties of dignity. Health Care Analysis [Internet]. 2004 [cited 2018 Oct 29]; 12(2):69-81. Available from: https://dx.doi.org/10.1023/B:HCAN.0000041183.78435.4b

33. Queiroz TA, Ribeiro ACM, Guedes MVC, Coutinho DRT, Galiza FT, Freitas MC. Experiences of death of older adults in medical practice and human dignity. Texto Contexto Enferm [Internet]. 2018 [cited 2018 Oct 29]; 27(1):3-10. Available from: https://dx.doi.org/10.1590/1983-80422016243158

34. Poletto S, Bettinelli LA, Santin JR. Vivências da morte de pacientes idosos na prática médica e dignidade humana. Rev. Bioét. [Internet]. 2016 [cited 2018 Oct 29]; 24(3):590-5. Available from: https://dx.doi.org/10.1590/1983-80422016243158

35. Silva HA, Viana GKB, Lima AKG et al. Intervention in palliative care: knowledge and perception of nurses. Rev enferm UFPE [Internet]. 2018 [cited 2018 Apr 29]; 12(5):1325-30. Available from: Available from: https://dx.doi.org/10.5205/1981-8963-v12i05a22653p1325-1330-2018

36. Poletto S, Bettinelli LA, Santin JR. Experiences of death of older adults in medical practice and human dignity. Rev. Bioet [Internet]. 2016 Dec [cited 2018 Oct 29]; 24(3):590-95. Available from: https://dx.doi.org/10.1590/1983-80422016243158

37. Yon Y, Mikton CR, Gassoumis ZD, Wilber KH. Elder abuse prevalence in community settings: a systematic review and meta-analysis. Lancet Global Health [Internet]. 2017 [cited 2018 Apr 17]; 5(2):147-56. Available from: https://dx.doi.org/10.1016/S2214-109X(17)30006-2

38. Santos FS, Saintrain MVL, Vieira LJES, Sampaio EGM. Characterization and Prevalence of Elder Abuse in Brazil. Journal of Interpersonal Violence [Internet]. 2018; [cited 2018 Oct 29]. Available from: https://dx.doi.org/10.1177/0886260518781806 
39. Carlos ACJ. Los Dilemas Bioéticos y Jurídicos relacionados con la muerte digna o el morir dignamente. Desde una dimensión medico-espiritual en el final de la vida. Rev Bioet Latinoam [Internet]. 2016 [cited 2018 Oct 17;17:35-60.]. Available from: http://www.saber.ula.ve/ handle/123456789/41613

40. Gomes ALZ, Othero MB. Cuidados Paliativos. Estud Avançados [Internet]. 2016 [cited 2018 Apr 19]; 30(88):155-66. Available from: https://dx.doi.org/10.1590/s0103-40142016.30880011 


\section{NOTES}

\section{ORIGIN OF THE ARTICLE}

Residency Completion Work "Perception of patients' sense of dignity in Palliative Care", Multiprofessional Health Residency Program of the Elderly in Palliative Care of the Universidade de Sao Paulo, School of Medicine, Hospital das Clínicas, 2018.

\section{CONTRIBUTION OF AUTHORITY}

Study design: Franco ME, Salvetti MG, Franck EM, Donato SCT.

Data collection: Franco ME.

Analysis and interpretation of data: Franco ME, Salvetti MG, Franck EM.

Discussion of the results: Franco ME, Salvetti MG, Franck EM.

Writing and/or critical review of content: Franco ME, Salvetti MG, Donato SCT, Franck EM, Carvalho RT. Review and final approval of the final version: Franco ME, Salvetti MG.

\section{ACKNOWLEDGMENT}

To Gabriela de Souza Stanzani for the interview transcripts and to Vinícius Gomes Barros for his help with the method.

\section{ETHICS COMMITTEE IN RESEARCH}

Approved by the Ethics Committee in Research with Human Beings of the Universidade de Sao Paulo, School of Medicine, Hospital das Clínicas, Opinion No.2,225,181, Certificate of Presentation and Ethical Appreciation $\mathrm{n}^{\circ}$ 71987317.5.0000.0068.

\section{CONFLICT OF INTERESTS}

There is no conflict of interest.

\section{HISTORICAL}

Received: April 26, 2018.

Approved: September 13, 2018.

\section{CORRESPONDENCE AUTHOR}

Marinete Esteves Franco

marinete.franco@hotmail.com 